\title{
The Development of Learning Media Réception Écrite Élémentaire WEB-Based
}

\author{
Hesti Fibriasari \\ Medan State University, Indonesia \\ hestifibriasari@ymail.com
}

\author{
Evi Eviyanti \\ Medan State University, Indonesia \\ eviyanti@gmail.com
}

\author{
Faisal Abas Siregar \\ Medan State University, Indonesia \\ faisal.abas@yahoo.com
}

\begin{abstract}
This study aims to determine the use of web media in learning Réception Écrite Élémentaire to be able to improve the ability and motivation of students in the Réception Écrite Élémentaire course. The method used in this research is Research and Development method. In this method, it uses 6 research steps to limit the problems, namely potential and problems, data collection, product design, design validation, design revision, and test the product. The result of this study shows that web media Réception Écrite Élémentaire is more efficient because the use of this media is very easy to use by students and lecturers. Both require web media Réception Écrite Élémentaire in learning. This web media can help students and lecturers of French in learning activities outside the classroom, because it is independent.
\end{abstract}

Keywords: learning media, réception écrite élémentaire, web

\section{INTRODUCTION}

Progress and development of information technology is very rapid in the digital era today and give a very big influence on the world of education. Progress and development is evidenced by the information that can be accessed easily, wherever and whenever. This condition has a positive impact on educators in order to exploit this situation by developing web-based learning. The advantages of web learning model in the learning process are flexibility by providing solutions of distance, time and space problems.

The learning process can still take place, wherever the learner is with an internet connection that helps the learner to learn independently without having to be in the classroom. The process helps lecturers to run three functions of college they are teaching, researching and performing devotion. Three functions of college will be able to walk by utilizing advanced technology in the current global era.

Four language competencies in language learning are competence of speaking, writing, reading and listening. The four competencies are compulsory and tiered courses given from beginner to advanced level. One such course is a reading course that requires students to read French texts. The use of web media in reading courses can help students to learn independently wherever students are located.

The competences of reading text and understanding the contents of a text such as a new sentence, a question sentence using appropriate words and intonation. In understanding a text, reading ability, discussion and writing ability are the primary goal of this lesson for beginners at A1 level. At A1 level, the learners are expected to understand and use standard expressions in daily use with real and very basic vocabulary. Learners can introduce themselves and introduce someone like a place to live, a relationship with a person, and a family situation. Learners can also answer simple questions.
The method of reading teaching, teachers use good learning media. The use of learning media can motivate learners, one of them by using web media. Today, technological advances are very rapid and information media is more advanced and can be used in learning. Technologies in that learning are elearning, online learning, web-based training, online courses, and web-based education. Learning technology requires teachers to create innovations in French learning. Informatics technology is growing rapidly with internet connections everywhere now making it easier for French learners to learn French.

Many facilities are offered on learning elearning, especially for learning to read the French on the Réception écrite élémentaire course by Discovery Learning et Problem Based Learning model. The use of the learning model makes the learners independent and lecturers only be facilitator and provide input in the form of suggestions and learners can easily use the learning module with internet access very easily.

\section{METHODS}

This research uses R \& D method. Research and development is a research development based on the results of needs analysis in the presence of conditions in the field. The result of product is a learning device in the form of books, media and the utilization of learning media. Research and development steps according to Sugiyono (2015) consist of 10 steps consisting of: (1) potential and problem; (2) gathering information; (3) product design; (4) validation of design; (5) revision of design; (6) test the product; (7) product revision; (8) trial of usage; (9) product revision; and (10) mass production.

From the tenth steps, the research in this first year only use six steps that are step no 1 to step no 6, this is because time trial in learning. The steps of R \& $\mathrm{D}$ research can be seen from the figure below (Figure $1)$. 


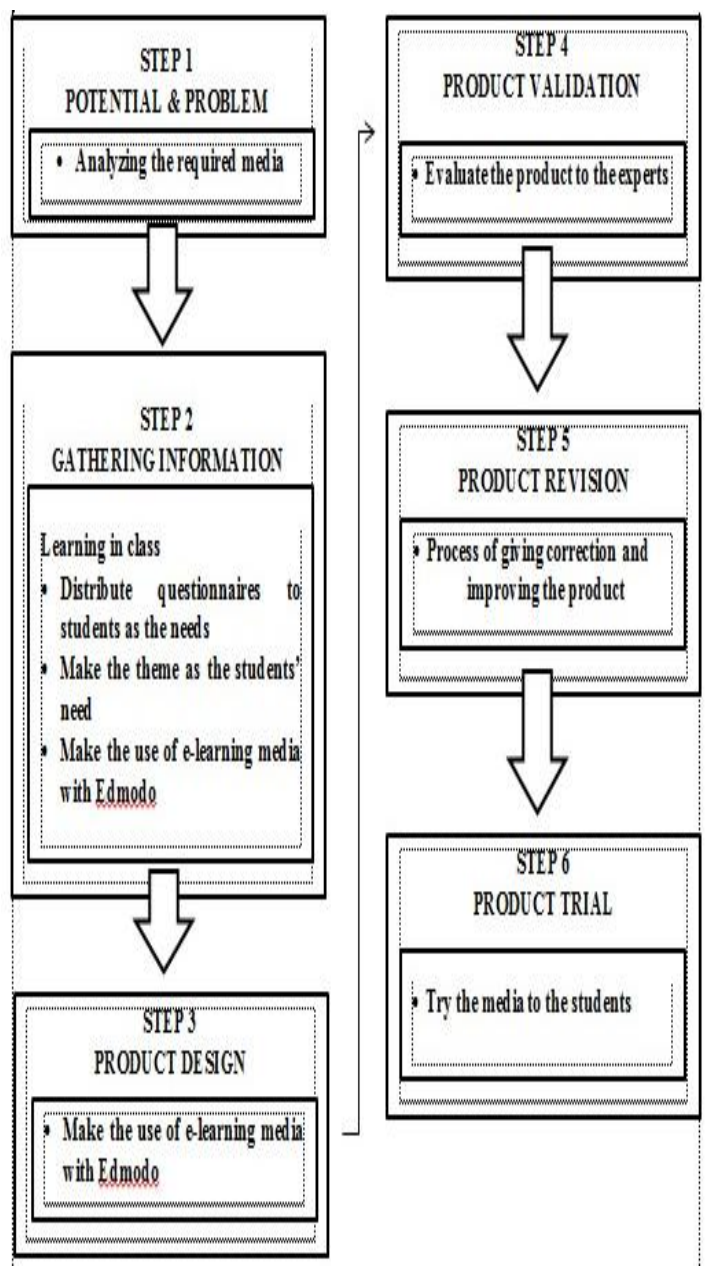

Figure 1

Research \& Development Stages

\section{Research Stages of Research \& Development}

Ten stages of research method in Research \& Development according to Sugiyono (2015: 409) which will be presented below, this research uses six steps, as follows:

1. Potential and problem. In this stage, the researchers discover the potential and problem that exist in the reading class in French Study Program Medan State University. Potential and problem are lecturers in learning French. Constraints faced by lecturers in teaching and learning process by classical by doing the process of learning in the classroom only. Oneway communication between lecturer and students occurs only in the classroom. The lack of communication between lecturers and parents about the development of learners during the lecture took place.

2. Gathering information. In accordance with the focus of research is the utilization of e-learning media in learning French in Medan State University by using the web to improve the ability of French language learners in Medan State University then needs analysis consists of the use of e-learning media by using the web and test the media. To analyze the needs, the first is done the questionnaires to the lecturers and students. Afterwards, questionnaires are distributed to lecturers who teach on four language competencies to know the result of product utilization of elearning media by using web.

3. Product design. In this study, the researchers design the use of learning media for learning four language competencies by using the web to improve the French language skills of Medan State University students. All will be presented in the development of learning media.

4. Concept. Media development by utilizing web media which is learning based e-learning. This application can facilitate learner and lecturer in communicating with long distance. Wherever the lecturers and students will be able to communicate, in addition to parents can monitor the learning activities through this application.

5. Design of learning media. This stage is done to create a learning design using the web in learning with four competencies in French study program Medan State University.

6. Validation. Researchers chose two experts in the using of IT and learning using web applications. The results of expert opinion show that e-learning 
has advantages and disadvantages in learning.

7. Product revision. After knowing the expert's opinion about the weakness of the product then the researchers did a revision in accordance with the input from the expert to improve the product to be implemented.

\section{Data Collection Techniques}

To know the data collection techniques in research, the researcher uses data collection techniques as follows:

1. Documentation. According to Sukmadinata (2008), documentary study is a technique of collecting data by collecting and analyzing documents which are in written, drawing, and electronic. The purpose of collecting documents in the collection of data is to select material to be presented in the form of written document, picture and electronic.

2. Questionnaire. Questionnaires are used after being validated by experts after the questionnaires are given to lecturers and students. Questionnaire is analyzed to be an instrument that will be used for the utilization of e-learning media to improve the four language competencies. Students' questionnaire results about the use of e-learning media become student motivation and distance learning using test. The result of the learning, this instrument can measure the ability and knowledge of students in learning French.

\section{Instrument Validation}

Instruments are validated with experts to see existing weaknesses and prototypes. Prototype of utilization of instructional media on four language competencies. Two lecturers provide input on the use of e-learning media to improve the utilization of media with good quality. The study was conducted in the French Language Education Program Medan State University. The object of research is the students of French Language Study Program semester 1 which takes the reading course by using web media. Data sources are students who study the course reading by using web media. The use of the application is in elearning.

\section{RESULT AND DISCUSSION}

The beginning is given a general idea of the actual state which is deviated from the object of searching. The initial goal is to find the reading problems to students of the $1^{\text {st }}$ semester. The data obtained earlier made basic needs analysis as a first step to make learning web media. Data collection is done by giving questionnaires to students so we know that we need this media or not. Depending on the results of the questionnaires, it can be seen that students need instructional media in basic write-up courses because there is little or no learning media used by teachers in teaching. So we have to have web media on reading lectures.

Based on the Table 1, we see that: (1) there are many students (97\%) who say they have the skills to read is very important; (2) there are students (82\%) who say they know about learning to use web media; (3) $45 \%$ of students said that they use learning media as learning web; and (4) all students say they need instructional media especially web learning in basic write-up courses. So, it can be concluded that students need an interesting media to improve learning outcomes.

Table 1

Student Perceptions

\begin{tabular}{|c|c|c|c|c|}
\hline No & Kind of Information & Answer & Number of Student & Percentage $(\%)$ \\
\hline \multirow[t]{2}{*}{1} & Have reading skill in French Text is important & Yes & 28 & 97 \\
\hline & & No & 1 & 3 \\
\hline \multirow[t]{2}{*}{2} & Have known learning media web-based. & Yes & 24 & 82 \\
\hline & & No & 5 & 18 \\
\hline \multirow[t]{2}{*}{3} & Use learning media web-based in learning & Yes & 13 & 45 \\
\hline & process. & No & 16 & 55 \\
\hline \multirow[t]{2}{*}{4} & Require learning media web-based in learning & Yes & 29 & 100 \\
\hline & process & No & 0 & 0 \\
\hline
\end{tabular}

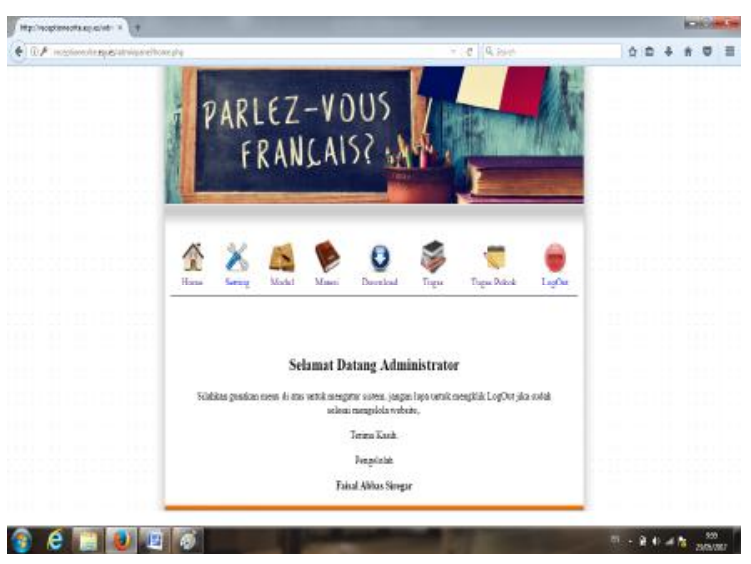

Figure 2

Web Design 


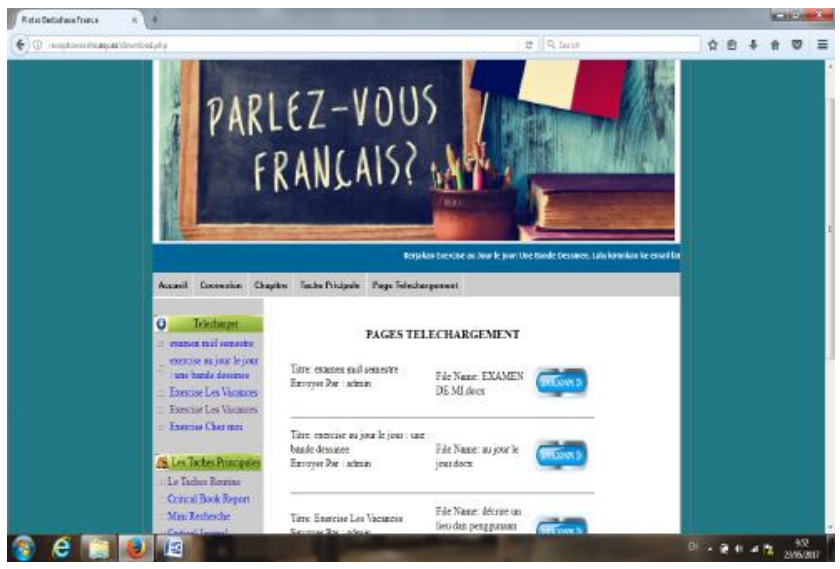

Figure 3

Web Design

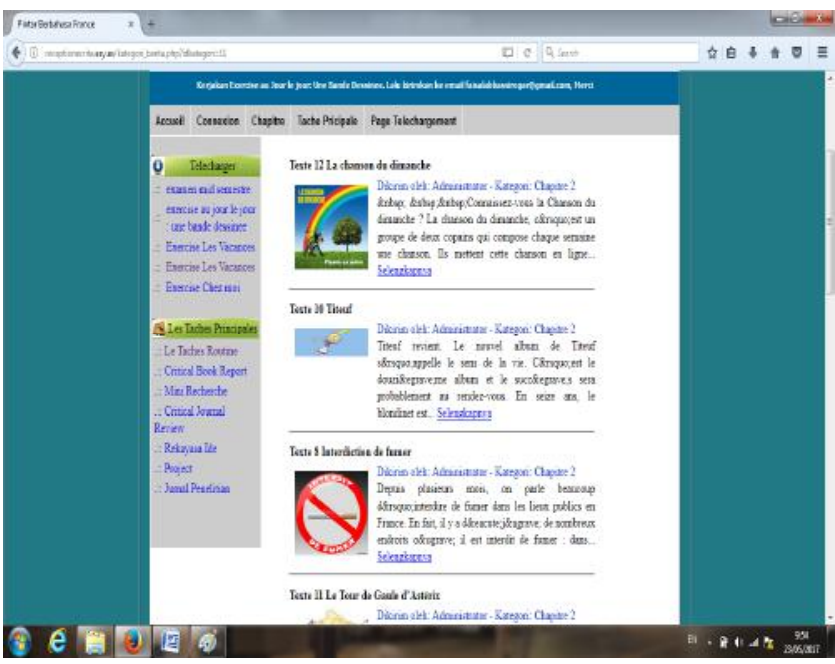

Figure 4

Web Design

Hamalik (2004) states learning objectives can be achieved well if supported by various factors, among other media education (media learning). Learning media is one of the factors to achieve teaching and learning process because teachers can provide learning materials. The use of instructional media is an alternative to attract the attention of learners, because it helps the learning process. On the other hand the internet helps the learner, according to Arsyad (2007) learning media can also help the learner in generating comprehension, complementing the data in interesting and extraordinary media, facilitating the interpretation of data and condensing information.

To develop the learning media, the authors will create an internet site to provide motivation in the process of written understanding on computer applications which is quite interesting where webbased learning media can be accessed for 24 hours with the use of the Internet network. In this study, the authors use Macromedia Dreamweaver8 computer applications to design web learning and this learning media can motivate students' interest to improve skills in Basic Written Admission course.

\section{CONCLUSION}

Teaching activities using web media can be used everywhere and not in the classroom. Teachers only give the instructions to students how to use web reading course. Like searching websites, selecting and deciding material, downloading questions, and trying answers to questions to teachers. Currently, the second semester students' competence to read simple French texts in foreign language Major to the French section of the academic year 2016/2017 is generally in the competent category. In addition, the use of basic web of receiving basic writing is effective so that it can be learned by everyone. In learning, the use of web media is very easy and effective for students and teachers. And there is a slight increase in value $(1.78 \%)$ and students' motivation between classes that are not used.

\section{ACKNOWLEDGMENT}

The research for this paper was financially supported by the Ministry of Research, Technology and Higher Education (RISTEK-DIKTI) and Medan State University, Number 045A/UN33.8/LL/2017. 


\section{REFERENCES}

[1] Andi. 2013. Teknik Singkat dan Cepat Menguasai CSS3. Yogyakarta: Wahana Komputer.

[2] Arsyad, A. 2007. Media Pembelajaran. Jakarta: Raja Grafindo Persada.

[3] Didik, D. P. 2003. Tip dan Trik Kolaborasi PHP dan MySQL. Jakarta: PT Elex Media Komputindo.

[4] Edyani. 2013. Pengembangan Bahan Ajar Berbasis Web pada Topik Teori Atom Mekanika Kuantum. Bandung: UPI.

[5] Fanany. 2012. Tekknik Membaca Cepat. Yogyakarta: Araska.

[6] Hamalik, O. 2004. Media pendidikan Bandung : Citra Aditya Bakti

[7] Haryadi. 2006. Pokok-pokok Keterampilan Membaca. Semarang: UNNES

[8] Kridalaksana, H. 2008. Kamus Linguistik. Jakarta: Gramedia Pustaka Utama.

[9] Polili, A. 2008. Pengembangan Model Pembelajaran Audition Prononciation Berbasis Web. Medan: UNIMED.

[10] Sadiman. 2002. Media pendidikan: Pengertian, Pengembangan dan Pemanfaatannya. Jakarta: Pustekkom.

[11] Siregar, T. 2014. Membangun Aplikasi Iklan Penjualan Mesin Fotocopy \& Printer di Firm Sejati Berbasis Website Dengan Metode Competitive Advantages. Medan: STT Harapan.

[12] Sugiyono. 2015. Metode Penelitian Pendidikan (Pendekatan Kuantitatif, Kualitatif dan $R \& D$ ). Bandung: Alfabeta.

[13] Sukmadinata, N. S. 2008. Metode Penelitian Pendidikan. Bandung: Remaja Rosdakarya.

[14] Swastika, 2006. Dasar-dasar Pengenalan PHP untuk Orang Awam. Jakarta: Andi Publisher.

[15] Tarigan, H. G. 2009. Keterampilan Membaca dan Berbahasa. Bandung: Angkasa Jaya. 